\title{
Erythromycin and GC7 fail as domain-specific inhibitors for bacterial and archaeal activity in the open ocean
}

\author{
Alexander H. Frank ${ }^{1}$, Benjamin Pontiller ${ }^{1,3}$, Gerhard J. Herndl ${ }^{1,2}$, \\ Thomas Reinthaler ${ }^{1, *}$
}

\author{
${ }^{1}$ Dept. of Limnology and Bio-Oceanography, University of Vienna, 1090 Vienna, Austria \\ ${ }^{2}$ Dept. of Biological Oceanography, Royal Netherlands Institute for Sea Research, 1790AB Den Burg, Texel, The Netherlands \\ ${ }^{3}$ Present address: Centre for Ecology and Evolution in Microbial Model Systems, Linnaeus-University, 39182 Kalmar, Sweden
}

\begin{abstract}
Domain-specific metabolic inhibitors are currently used to differentiate archaeal from bacterial activity. However, studies testing the specificity of these inhibitors are sparse or are based on cultured strains. We determined the inhibition specificity of erythromycin (EMY) and N1-guanyl-1,7-diaminoheptane (GC7) on bacterial and archaeal communities in the North Atlantic. EMY and GC7 are assumed to inhibit bacterial and archaeal activity, respectively. Heterotrophic prokaryotic activity was estimated via ${ }^{3} \mathrm{H}$-leucine incorporation on the cell-specific level using catalyzed reporter deposition fluorescence in situ hybridization combined with microautoradiography (MICRO-CARD-FISH). In the water masses studied, the contribution of Thaumarchaeota to total picoplankton abundance ranged from 5 to $24 \%$ while Euryarchaeota contributed 2 to $6 \%$; the relative abundance of Bacteria ranged from 29 to $48 \%$. The addition of EMY and GC7 reduced the bulk leucine incorporation by $\sim 77 \%$ and $\sim 41 \%$, respectively. Evaluation of the inhibition efficiency of EMY on a cell-specific level showed no difference between Archaea $(76.0 \pm 14.2 \%[\mathrm{SD}])$ and Bacteria $(78.2 \pm 9.5 \%)$. Similarly, the reduction of substrate uptake in GC7-treated samples was similar in Archaea (59.9 $\pm 24 \%$ ) and Bacteria (47.2 $\pm 9.6 \%$ ). Taken together, our results suggest that in complex open-ocean prokaryotic communities neither EMY nor GC7 is efficient as a domain-specific inhibitor.
\end{abstract}

KEY WORDS: N1-guanyl-1,7-diaminoheptane $\cdot$ Secondary production $\cdot$ Prokaryotes $\cdot$ MICROCARD-FISH · Dark ocean ·Antibiotics · North Atlantic Ocean · Microautoradiography

\section{INTRODUCTION}

Over the last 2 decades, it has become apparent that both Archaea and Bacteria are major components of the microbial community in the oceanic water column (Karner et al. 2001, Herndl et al. 2005, Teira et al. 2006a). While the contribution of Bacteria to total picoplankton abundance decreases with depth, the relative contribution of mesophilic Archaea increases toward the deep-water masses where Euryarchaeota and Thaumarchaeota contribute up to $50 \%$ to the

${ }^{*}$ Corresponding author: thomas.reinthaler@univie.ac.at total picoplankton abundance (Karner et al. 2001, Teira et al. 2006a, Varela et al. 2008). Thaumarchaeota play a significant role in the first step of nitrification, utilizing ammonia (Könneke et al. 2005, Wuchter et al. 2006, Francis et al. 2007) as an energy source, and chemoautotrophically fix carbon dioxide for biomass synthesis (Herndl et al. 2005, Hallam et al. 2006). The dark ocean's chemoautotrophy is mainly attributed to Thaumarchaeota, while Bacteria are largely considered heterotrophic, suggesting that the main metabolic pathways are distinct between these 2 major

() The authors 2016. Open Access under Creative Commons by Attribution Licence. Use, distribution and reproduction are unrestricted. Authors and original publication must be credited. 
prokaryotic groups. However, at least some Archaea are able to take up amino acids (Ouverney \& Fuhrman 2000, Teira et al. 2006b) and use organic matter as a carbon source (Hallam et al. 2006). Indications of a mixotrophic lifestyle within this phylum have been found in metagenomic libraries from bathypelagic samples (Martin-Cuadrado et al. 2008).

Catalyzed reporter deposition fluorescence in situ hybridization, combined with micro-autoradiography (MICRO-CARD-FISH) is a well-established method to visualize the uptake of substrates by single cells (Teira et al. 2004, De Corte et al. 2013). MICROCARD-FISH helped in quantifying dissolved inorganic carbon fixation by Thaumarchaeota in the dark ocean (Herndl et al. 2005, Teira et al. 2006b). However, MICRO-CARD-FISH is labor- and time-consuming, particularly if one aims at estimating uptake rates at the individual cell level (Sintes \& Herndl 2006, Varela et al. 2011). A reliable and sensitive method using radiolabeled substrates in combination with group-specific antibiotics would be essential to distinguish between archaeal and bacterial activity in mixed communities (Levipan et al. 2007b, Yokokawa et al. 2012, Berg et al. 2015a).

Metabolic inhibitors or antibiotics inhibit the growth (bacteriostatic) or cause cell death (bactericidal) of most microorganisms by affecting the DNA, RNA, cell wall, or protein synthesis (Kohanski et al. 2010). For measuring the activity of specific microbial groups, bacteriostatic drugs are preferred over bactericidal antibiotics, as the latter might lead to the release of additional substrate via leaching of intracellular material through damaged membranes, potentially leading to stimulated growth of non-target groups. Macrolides such as erythromycin (EMY) inhibit the elongation of the nascent peptide chain that leaves the ribosomal exit tunnel of the 50S subunit (Wilson 2014). From studies on clinically important prokaryotes, it is assumed that EMY reversibly inhibits Bacteria, leaving Archaea and eukaryotes unaffected (Tu et al. 2005, Dunkle et al. 2010).

Despite their widespread occurrence in the guts of animals including humans, archaeal pathogens have not been identified thus far (Cavicchioli et al. 2003, Eckburg et al. 2003). Yet, some antibiotics such as diphtheria toxin have been found to inhibit eukaryotes and Archaea (Kessel \& Klink 1980). In a recent study, diphtheria toxin caused specific inhibition of Archaea in a natural microbial community of the North Atlantic (Yokokawa et al. 2012). However, diphtheria toxin is rather expensive and consequently is not suited for routine application in large sampling programs.
In a laboratory study, the cell cycle of several archaeal extremophiles was arrested by the addition of the spermidine analog N1-guanyl-1,7-diaminoheptane (GC7) (Jansson et al. 2000). In eukaryotes, GC7 irreversibly binds near the active center of the enzyme deoxyhypusine synthase (DHS) (Umland et al. 2004) and reversably also in Archaea (Jansson et al. 2000), thereby inhibiting the hypusination of the initiation factor eIF-5A (Murphey \& Gerner 1987, Park et al. 2006). The initiation factor eIF-5A and its homolog aIF-5A (Bartig et al. 1992, Eichler \& Adams 2005) are vital proteins for cell proliferation in eukaryotes and Archaea, respectively (Park et al. 2010). Kyrpides \& Woese (1998) reported a universal conservation of these translation initiation factors (EF-P in Bacteria). Nevertheless, it has been suggested that hypusine, a post-translationally modified amino acid, is absent in Bacteria (Gordon et al. 1987, Jansson et al. 2000). However, recent studies found functional DHS homologs in extensive BLAST searches that might indicate a probable role of hypusine in several bacterial species (Brochier et al. 2004, López-García et al. 2004). The exact functions and mechanisms by which the IF-5A reacts in the eukaryotic cell and which function it has, however, are still under debate (Zanelli \& Valentini 2007). Nevertheless, GC7 has recently been proposed as an inexpensive and efficient inhibitor for Archaea (Levipan et al. 2007a,b, Farias et al. 2009). However, knowledge on the specificity of GC7 in Archaea is based on a few culture experiments with simple community composition (Jansson et al. 2000, Löscher et al. 2012, Berg et al. 2015b). Consequently, the specificity of GC7 has not been extensively tested on complex natural microbial assemblages.

Therefore, the objective of this study was to test the specificity of the 2 widely used inhibitors EMY and GC7 on natural, complex prokaryotic assemblages throughout the water column of the North Atlantic and to determine the relative contribution of Bacteria and Archaea to the bulk heterotrophic microbial activity. We measured bulk heterotrophic activity via ${ }^{3} \mathrm{H}$-leucine incorporation and used MICRO-CARD-FISH combined with automated cell counting to evaluate the cell-specific activity of BaCteria and Archaea in the presence and absence of these metabolic inhibitors. While the bulk measurements suggested selective inhibition of microorganisms, cell-specific analyses revealed that neither EMY nor GC7 are sufficiently specific to allow a clear differentiation of archaeal from bacterial activity by using these 2 inhibitors on complex prokaryotic communities. 


\section{MATERIALS AND METHODS}

\section{Sample collection}

During a North Atlantic Cruise (MEDEA-2) with the RV 'Pelagia' between 21 June and 22 July 2012, seawater samples of $25 \mathrm{l}$ each were taken at 7 stations between 49 and $64^{\circ} \mathrm{N}$ and between 6 and $40^{\circ} \mathrm{W}$ using 19 Niskin bottles (Ocean Test Equipment) mounted on a rosette frame equipped with a conductivity, temperature, depth (CTD, SBE911plus, Sea-Bird Electronics), and oxygen sensor (SBE 43, Sea-Bird Electronics). Before each operation, the sensors were re-calibrated for drift (WOCE operations manual 1994). Deep-water masses were identified by salinity-temperature plots. The samples for the inhibition experiments were collected from the subsurface layer $(\mathrm{SSL}, \sim 100 \mathrm{~m})$, the relative oxygen minimum layer $\left(\mathrm{O}_{2}\right.$-min, $\left.\sim 500 \mathrm{~m}\right)$, the upper Labrador Sea Water (uLSW, 1000 m), and the Norwegian Sea Deep Water (NSDW, $\sim 3000 \mathrm{~m}$ ). The physico-chemical properties of the water masses are presented in Table 1.

\section{Picoplankton abundance}

Picoplankton abundance was determined by flow cytometry (Marie et al. 1997). Briefly, duplicate sea- water samples were fixed with electron microscopygrade glutaraldehyde $(0.5 \%$ final concentration), flash-frozen in liquid nitrogen, and stored at $-80^{\circ} \mathrm{C}$ until analysis. In the home laboratory, the samples were thawed and stained with SYBR Green I (Life Technologies) in the dark for $10 \mathrm{~min}$. Cytograms of side scatter versus fluorescence (excitation at $488 \mathrm{~nm}$, emission at $530 \mathrm{~nm}$ ) were used to identify picoplankton cells on an Accuri C6 flow cytometer (BD Biosciences). Counts were calibrated with known concentrations of fluorescent $1 \mu \mathrm{m}$ plastic spheres (Molecular Probes).

\section{Treatments with antibiotics}

Based on the results of the pre-exposure and concentration tests, 60 min prior to adding ${ }^{3} \mathrm{H}$-leucine the antibiotics were added to parallel sets of seawater samples. For inhibition of Bacteria, seawater samples were incubated according to T. Yokokawa (pers. comm.) with EMY (Sigma-Aldrich, stock solution: $13.6 \mathrm{mmol} \mathrm{L}^{-1}$ in ethanol), at a final concentration of $68 \mu \mathrm{mol} \mathrm{L}^{-1}$. For the inhibition of Archaea, seawater samples were incubated following Jansson et al. (2000) with GC7 (Biosearch Technologies, stock solution: $50 \mathrm{mmol} \mathrm{L}^{-1}$ in acetic acid) at a final concentration of $1.0 \mathrm{mmol} \mathrm{L}^{-1}$. Volumes of the incubations

Table 1. Geographic location and physico-chemical characteristics of the sampled water masses (WM). SSL: subsurface layer $(\sim 100 \mathrm{~m}) ; \mathrm{O}_{2}$-min: oxygen-minimum of the water column at that station; uLSW: upper Labrador Sea Water; NSDW: Norwegian Sea Deep Water; TRNS: transitional; ND: not determined

\begin{tabular}{|c|c|c|c|c|c|c|c|c|c|c|c|}
\hline $\begin{array}{l}\mathbf{W M} \\
\text { Stn }\end{array}$ & $\begin{array}{l}\text { Lat. } \\
\left({ }^{\circ} \mathrm{N}\right)\end{array}$ & $\begin{array}{l}\text { Long. } \\
\left({ }^{\circ} \mathrm{E}\right)\end{array}$ & $\begin{array}{l}\text { Depth } \\
\text { (m) }\end{array}$ & $\begin{array}{l}\text { Temp. } \\
\left({ }^{\circ} \mathrm{C}\right)\end{array}$ & Salinity & $\begin{array}{c}\sigma_{\theta} \\
\left(\mathrm{kg} \mathrm{m}^{-3}\right)\end{array}$ & $\begin{array}{c}\mathrm{NH}_{4} \\
\left(\mu \mathrm{mol} \mathrm{kg}{ }^{-1}\right)\end{array}$ & $\begin{array}{c}\mathrm{NO}_{3} \\
\left(\mu \mathrm{mol} \mathrm{kg}{ }^{-1}\right)\end{array}$ & $\begin{array}{c}\mathrm{PO}_{4} \\
\left(\mu \mathrm{mol} \mathrm{kg}{ }^{-1}\right)\end{array}$ & $\begin{array}{c}\mathrm{Si} \\
\left(\mu \mathrm{mol} \mathrm{kg}{ }^{-1}\right)\end{array}$ & $\begin{array}{c}\mathrm{O}_{2} \\
\left(\mu \mathrm{mol} \mathrm{kg}{ }^{-1}\right)\end{array}$ \\
\hline \multicolumn{12}{|l|}{ SSL } \\
\hline 8 & 51.34 & 326.87 & 98 & 11.0 & 35.23 & 26.95 & 0.14 & 9.54 & 0.63 & 4.08 & 253 \\
\hline 12 & 53.38 & 319.93 & 99 & 5.5 & 34.79 & 27.45 & 0.15 & 18.76 & 1.18 & 10.02 & 243 \\
\hline 18 & 57.62 & 332.19 & 99 & 8.3 & 35.03 & 27.25 & 0.14 & 13.59 & 0.88 & 5.44 & 262 \\
\hline 20 & 61.32 & 341.89 & 99 & 8.9 & 35.20 & 27.28 & 0.13 & 12.62 & 0.82 & 4.39 & 263 \\
\hline 22 & 64.07 & 354.1 & 99 & 3.4 & 34.93 & 27.80 & 0.47 & 10.39 & 0.74 & 4.15 & 302 \\
\hline \multicolumn{12}{|l|}{$\mathrm{O}_{2}$-min } \\
\hline 8 & 51.34 & 326.87 & 392 & 6.7 & 34.88 & 27.37 & 0.11 & 18.90 & 1.24 & 10.73 & 218 \\
\hline 12 & 53.38 & 319.93 & 495 & 4.0 & 34.88 & 27.69 & 0.13 & 16.59 & 1.09 & 8.45 & 290 \\
\hline 20 & 61.32 & 341.89 & 726 & 7.0 & 35.15 & 27.54 & 0.11 & 18.27 & 1.18 & 10.07 & 225 \\
\hline 22 & 64.07 & 354.1 & 248 & 1.9 & 34.97 & 27.96 & 0.08 & 13.73 & 0.92 & 5.47 & 291 \\
\hline \multicolumn{12}{|l|}{ uLSW } \\
\hline 8 & 51.34 & 326.87 & 1086 & 4.0 & 34.92 & 27.73 & 0.08 & 17.28 & 1.12 & 10.05 & 274 \\
\hline 12 & 53.38 & 319.93 & 989 & 3.7 & 34.89 & 27.73 & 0.13 & 17.09 & 1.11 & 9.68 & 281 \\
\hline 20 & 61.32 & 341.89 & 988 & 5.1 & 35.01 & 27.68 & 0.10 & 18.44 & 1.20 & 10.90 & 247 \\
\hline $\begin{array}{l}\text { NSDW } \\
22\end{array}$ & 64.07 & 354.1 & 3137 & -0.8 & 34.91 & 28.08 & 0.05 & 15.69 & 1.04 & 14.07 & 282 \\
\hline \multicolumn{12}{|c|}{ Samples taken to determine pre-exposure time and concentration of inhibitors } \\
\hline & 49.23 & 347.98 & 823 & 9.9 & 35.63 & 27.47 & $N D$ & $N D$ & $N D$ & $N D$ & 191 \\
\hline $\begin{array}{l}\mathrm{O}_{2}-\mathrm{min} \\
5\end{array}$ & 51.3 & 336.55 & 689 & 8.9 & 35.28 & 27.36 & $N D$ & $N D$ & $N D$ & $N D$ & 194 \\
\hline
\end{tabular}


were chosen depending on depth and the measured parameter (see next section). After the pre-exposure time at in situ temperature in the dark, the samples were processed as described below for the bulk leucine incorporation or MICRO-CARD-FISH.

\section{Bulk leucine incorporation and MICRO-CARD-FISH}

Bulk leucine incorporation by heterotrophic picoplankton was determined following Reinthaler et al. (2010). Briefly, for each treatment and control, triplicate water samples of 10 to $40 \mathrm{~mL}$ (depending on sampling depth) and 2 formaldehyde-treated blanks ( $2 \%$ final concentration) were spiked with ${ }^{3} \mathrm{H}$-leucine (specific activity $120 \mathrm{Ci} \mathrm{mmol}^{-1}$, PerkinElmer) to final concentrations of $5 \mathrm{nmol} \mathrm{L}^{-1}$ in the $\mathrm{O}_{2}$-min, uLSW, and NSDW samples, and $10 \mathrm{nmol} \mathrm{L^{-1 }}$ in the SSL samples. Following incubation at in situ temperature in the dark for $4 \mathrm{~h}$ (SSL), $12 \mathrm{~h}\left(\mathrm{O}_{2}\right.$-min and uLSW), or $24 \mathrm{~h}$ (NSDW), the samples were filtered through $0.2 \mu \mathrm{m}$ polycarbonate filters (Nuclepore, Whatman) supported by $0.45 \mu \mathrm{m}$ cellulose nitrate filters (HAWP, Millipore) and rinsed twice with $5 \mathrm{~mL}$ of an ice-cold aqueous solution of $5 \%$ trichloroacetic acid (ACSgrade, Sigma-Aldrich), transferred to $20 \mathrm{~mL}$ scintillation vials and allowed to dry at room temperature. Scintillation cocktail (8 mL; FilterCount, CanberraPackard) was added, and after $18 \mathrm{~h}$ the filters were counted on a Tricarb 3100TR scintillation counter (Perkin Elmer). The disintegrations per minute (dpm) were corrected for quenching with internal and external standards. The leucine incorporation rate was calculated using the dpm of live samples corrected for the readings of the formaldehyde-treated blanks.

In parallel with the bulk leucine incorporation measurement, MICRO-CARD-FISH was performed according to Teira et al. (2004). Briefly, ${ }^{3} \mathrm{H}$-leucine was added to the inhibitor-treated and control seawater samples $(20-80 \mathrm{~mL})$ with concentrations equal to the bulk measurements. Incubation time and temperature were chosen accordingly. At the end of the incubations, formaldehyde was added at a final concentration of $2 \%$. Following fixation for $18 \mathrm{~h}$ at $4{ }^{\circ} \mathrm{C}$, the samples were filtered through $0.2 \mu \mathrm{m}$ pore size polycarbonate filters (GTTP, Millipore) and rinsed twice with Milli-Q water. The filters were allowed to dry at room temperature for several minutes and stored in microfuge vials at $-80^{\circ} \mathrm{C}$ until further processing.

Back in the lab, the filters were thawed and embedded in $0.1 \%$ low-gelling-point agarose and subsequently dried at $37^{\circ} \mathrm{C}$ for $10 \mathrm{~min}$. Cell wall per- meabilization was achieved with lysozyme $(10 \mathrm{mg}$ $\left.\mathrm{mL}^{-1}, 37^{\circ} \mathrm{C}, 1 \mathrm{~h}\right)$ for Bacteria and $\mathrm{HCl}\left(0.1 \mathrm{~mol} \mathrm{~L}^{-1}\right.$, $20^{\circ} \mathrm{C}, 1 \mathrm{~min}$ ) for Archaea. Hybridization was performed with horseradish peroxidase-labeled probes specific for Bacteria, SAR11, Thaumarchaeota, and Euryarchaeota, additionally with Non-EUB338 (for probe sequences and hybridization conditions see Table S1 in the Supplement at www.int-res.com/ articles/suppl/a077p099_supp.pdf) provided at a ratio of 1:20 of probe to hybridization buffer at $35^{\circ} \mathrm{C}$ for $16 \mathrm{~h}$ in the dark in rotating vials $\left(5 \mathrm{rpm} \mathrm{min}{ }^{-1}\right)$. Signal amplification was performed by incubating filter sections in a substrate mix of 1:100 dilution of tyramides linked to the fluorescent dye Atto488 in an amplification buffer in the presence of $\mathrm{H}_{2} \mathrm{O}_{2}$ (final concentration $0.0015 \%$ ) at $37^{\circ} \mathrm{C}$ for $40 \mathrm{~min}$.

In a darkroom, the hybridized filter sections were transferred onto pre-cleaned microscopic glass slides coated with photographic emulsion (Ilford K.5; Ilford Photo) to a thickness of $\sim 10 \mu \mathrm{m}$. The slides were incubated at $4^{\circ} \mathrm{C}$ in a light-tight box containing silica beads for 6 to $8 \mathrm{~d}$. The exposure time for autoradiography was optimized, based on tests, where sections of each filter were screened for silver granules without prior hybridization. To prevent systematic variation between treatments and control due to handling, emulsion thickness, or emulsion age, corresponding filter sections were incubated on the same slide. After exposure, the slides were developed and fixed according to the manufacturer's specification (Ilford Photo). The filter sections were peeled off as described by Samo et al. (2014) using a cold spray (Cold 75 Super; CRC Industries Europe BVBA). The cells on the microscopic slides were counterstained and mounted in a mix of Vectashield (Vector Laboratories), phosphate-buffered saline, and Citifluor in a dilution ratio of 1:2:12, containing $1 \mu \mathrm{g} \mathrm{mL}^{-1} 4^{\prime}, 6$ diamino-2-phenylindole (DAPI).

\section{Microscopic image acquisition and evaluation}

Microscopy was performed on an epifluorescence microscope (Axio Imager M2, Carl Zeiss), equipped with an oil-immersion objective lens (Plan-Apochromat 100×/1.46, Carl Zeiss) and a black-and-white high-resolution camera (AxioCam MRm, Carl Zeiss). For each filter section, at least 10 pictures with a total of more than 300 DAPI-stained cells were taken using the filter sets for Atto488 and DAPI in the epifluorescence as well as the transmission mode. A set of 3 pictures was overlaid and the composite pictures were evaluated using custom-made software (DotAre, A. 
H. Frank et al. unpubl. data). The size of silver-grain halos around cells, indicative of the uptake of radiolabeled tracer, was measured. The software parameters for detection of cells and silver-grain halos were optimized with a training set of 10 manually counted pictures using the whole range of possible configurations. The software-annotated pictures were manually controlled. Microbial cells were classified as probe-positive if a DAPI-stained cell showed a fluorescence signal of the specific hybridization probe. Probe-negative cells were those visibly stained with DAPI only. All fluorescent cells were checked for overlap with a silver-grain halo. Distinct Atto488 fluorescence, but without DAPI signal, were also classified as leucine-positive cells. The percentage of cells with silver-grain halo but no DAPI fluorescence was $2.4 \pm 2.3 \%$. Hybridization with Non-EUB338 probe, to determine the percentage of unspecific binding, yielded $1.4 \pm 0.4 \%(\mathrm{n}=13)$ probe-positive cells.

\section{Cell-specific and group-specific leucine uptake}

Bulk leucine incorporation was normalized to the respective total cell-bound silver-grain area. Subsequently, the obtained ratio with units of nmol Leu $\mathrm{d}^{-1}$ $\mu \mathrm{m}^{-2}$ was multiplied with the silver-grain area associated with leucine-positive cells and normalized to the cell abundance of the filter area. This resulted in an average probe-positive cell-specific leucine uptake rate per day in units of amol cell ${ }^{-1} \mathrm{~d}^{-1}$.

The bulk leucine incorporation was divided by the total cell-bound silver-grain halo area and multiplied with the silver-grain halo area of the specific probepositive cells to determine the cell-specific leucine incorporation per prokaryotic group (in units of nmol $\left.\mathrm{m}^{-3} \mathrm{~d}^{-1}\right)$.

\section{Calculation of inhibition efficiency, specificity, and statistics}

To account for the filter-associated variability of total probe-positive cells, we normalized the activity based on the encountered probes in each treatment via the probe-specific activity (PSA):

$$
\mathrm{PSA}=P_{a} / P_{t}
$$

where $P_{a}$ is either the count of active probe-positive cells or the silver-grain halo area and $P_{t}$ is the total number of probe-positive cells.

The inhibition efficiency (IE) was determined as the ratio of the group-specific leucine uptake of the inhibitor-treated sample $\left(\mathrm{PSA}_{\text {treat }}\right)$ and its respective control $\left(\mathrm{PSA}_{\mathrm{ctr}}\right)$ :

$$
\mathrm{IE}=\left[1-\left(\mathrm{PSA}_{\text {treat }} / \mathrm{PSA}_{\mathrm{ctrl}}\right)\right] \times 100 \%
$$

To calculate the inhibition specificity (IS) of each inhibitor, the determined IE based on cell abundance and silver-grain halo area was used:

$$
\mathrm{IS}=\left(\mathrm{IE}_{\mathrm{TG}}-\mathrm{IE}_{\mathrm{NTG}}\right) / \mathrm{IE}_{\mathrm{NTG}}
$$

Depending on the inhibitor used, the target group (TG) and the non-target group (NTG) of the inhibitor are either the archaeal or bacterial taxa.

Possible treatment-related or a non-random cellloss effect during the peeling of the filter after microautoradiography was determined for each treatment by comparing the ratio of bacterial to thaumarchaeotal cell abundance using 1-way analysis of variance (ANOVA). All statistical prerequisites for ANOVA were tested and met. No statistical difference was found between the treatments. All statistical analyses were conducted with SigmaPlot Version 12. Values are given as mean $\pm \mathrm{SD}$ if not stated otherwise.

\section{RESULTS AND DISCUSSION}

\section{Characterization of the pelagic prokaryotic community and its environment}

Water samples were collected in the North Atlantic at 7 stations between 49 and $64^{\circ} \mathrm{N}$ and from 100 to $3100 \mathrm{~m}$ depth (Fig. S1 in the Supplement at www. int-res.com/articles/suppl/a077p099_supp.pdf). The physico-chemical characteristics of the depth horizons sampled were similar to recent surveys in the North Atlantic (Table 1) (Reinthaler et al. 2013). The prokaryotic abundance ranged from $4.1 \times 10^{5}$ cells $\mathrm{mL}^{-1}$ in the epipelagic SSL (100 m depth) to $0.6 \times 10^{5}$ cells $\mathrm{mL}^{-1}$ in the bathypelagic NSDW.

The relative abundance of Bacteria determined by CARD-FISH was $41 \pm 6 \%$ in the lower epi- and upper mesopelagic zone, and $37 \pm 7 \%$ in the uLSW (Table 2). Similarly, in the NSDW, $37 \%$ (n = 1 water sample) of the picoplankton were identified as Bacteria. Generally, the relative percentage of Bacteria was in agreement with an earlier study of the northern North Atlantic deep waters (Teira et al. 2006a). The SAR11 clade dominated the bacterial community, contributing $21 \pm 9 \%$ to the total picoplankton abundance (Table 2). A similar contribution of SAR11 to total picoplankton abundance was recently reported for the North Atlantic (Lekunberri et al. 2013). 
Table 2. Microbial abundance, leucine uptake, and major prokaryotic groups assessed by CARD-FISH in the northern North Atlantic. Abbreviations for water masses (WM) as in Table 1; PA-F: prokaryotic abundance measured by flow cytometry, Leu incorp: ${ }^{3} \mathrm{H}$ leucine incorporation

\begin{tabular}{|c|c|c|c|c|c|c|}
\hline $\begin{array}{l}\mathbf{W M} \\
\text { Stn }\end{array}$ & $\begin{array}{c}\text { PA-F } \\
\left(\text { cells } \mathrm{mL}^{-1} \times 10^{4}\right)\end{array}$ & $\begin{array}{l}\text { Leu incorp } \\
\left(\mathrm{nmol} \mathrm{m}^{-3} \mathrm{~d}^{-1}\right)\end{array}$ & $\begin{array}{c}\text { Bacteria } \\
(\%)\end{array}$ & $\begin{array}{c}\text { SAR11 } \\
\%\end{array}$ & $\begin{array}{c}\text { Thaumarchaeota } \\
(\%)\end{array}$ & $\begin{array}{c}\text { Euryarchaeota } \\
(\%)\end{array}$ \\
\hline \multicolumn{7}{|l|}{ SSL } \\
\hline 8 & 40.78 & 96.15 & 48 & 13 & 8 & 5 \\
\hline 12 & 22.37 & 21.79 & 39 & 22 & 12 & 2 \\
\hline 18 & 30.05 & 39.32 & 40 & 16 & 12 & 2 \\
\hline 20 & 30.18 & 25.30 & 36 & 12 & 6 & 2 \\
\hline 22 & 39.58 & 75.58 & 38 & 30 & 5 & 6 \\
\hline \multicolumn{7}{|c|}{$\mathrm{O}_{2}-\min$} \\
\hline 8 & 17.48 & 12.65 & 43 & 36 & 18 & 6 \\
\hline 12 & 15.09 & 6.31 & 44 & 20 & 20 & 3 \\
\hline 20 & 13.06 & 4.81 & 30 & 16 & 24 & 2 \\
\hline 22 & 25.50 & 18.22 & 49 & 30 & 21 & 3 \\
\hline \multicolumn{7}{|c|}{ uLSW } \\
\hline 8 & 7.59 & 2.27 & 40 & 16 & 10 & 2 \\
\hline 12 & 7.80 & 1.32 & 43 & 15 & 11 & 3 \\
\hline 20 & 8.92 & 2.20 & 29 & 13 & 14 & 4 \\
\hline \multicolumn{7}{|c|}{ NSDW } \\
\hline 22 & 5.92 & 1.35 & 37 & 36 & 10 & 5 \\
\hline
\end{tabular}

The relative abundance of Thaumarchaeota was also in the range of earlier reports from this region of the North Atlantic (Teira et al. 2006a, Yokokawa et al. 2012, Lekunberri et al. 2013) and highest in the $\mathrm{O}_{2}$-minimum layer with $21 \pm 3 \%$ of total picoplankton abundance and lowest in the SSL with $9 \pm 3 \%$. Over the whole water column, thaumarchaeotal relative abundance ranged from $\sim 5$ to $24 \%$ (Table 2). The contribution of Euryarchaeota to the total picoplankton abundance was low and rather constant from the epi- to the bathypelagic zone of the North Atlantic, averaging $3 \pm 2 \%$ (Table 2 ).

The total coverage of the picoplankton community with CARD-FISH using our complementary set of probes (see Table S1 in the Supplement for probes used in this study) ranged from 44 to $73 \%$ of all DAPI-positive cells, which is similar to the recovery efficiency reported in earlier studies (Karner et al. 2001, Church et al. 2003, Teira et al. 2004). The community composition determined by CARD-FISH did not correlate with salinity, temperature, or inorganic nutrients in the different water masses (Table 2). Bulk leucine incorporation rates decreased from $52 \pm$ $33 \mathrm{nmol} \mathrm{m}^{-3} \mathrm{~d}^{-1}$ in the SSL to $1.9 \pm 0.5 \mathrm{nmol} \mathrm{m}^{-3} \mathrm{~d}^{-1}$ in the uLSW and $1.4 \mathrm{nmol} \mathrm{m} \mathrm{m}^{-3} \mathrm{~d}^{-1}$ in the NSDW (Table 2). Bulk leucine uptake was correlated with depth and prokaryotic abundance (Tables S2 \& S3 in the Supplement).

Cell-specific leucine incorporation rate (i.e. bulk leucine incorporation/abundance of leucine-positive cells determined by MICRO-CARD-FISH) decreased with depth and ranged from 2.1 to 0.01 amol Leu cell $^{-1} \mathrm{~d}^{-1}$ (Table 3 ). The percentage of cells taking up leucine did not significantly change between the water masses (Table 3). Thus, the number of leucinepositive cells decreased with the general depthrelated trend (Table 2). Assuming a theoretical conversion factor of $1.55 \mathrm{~kg} \mathrm{C} \mathrm{mol}{ }^{-1}$ leucine with no isotope dilution (Simon \& Azam 1989) and an average carbon content of $10 \mathrm{fg} \mathrm{C}$ cell $^{-1}$ (Ducklow et al. 2000) resulted in doubling times of $4 \pm 3 \mathrm{~d}$ in the SSL, $18 \pm$ $10 \mathrm{~d}$ in the $\mathrm{O}_{2}-\min , 54 \pm 16 \mathrm{~d}$ in the uLSW, and $47 \mathrm{~d}$ in the NSDW. These turnover times are in agreement with other studies of the meso- and bathypelagic realm of the North Atlantic (Reinthaler et al. 2006).

\section{Pre-exposure time and concentration of EMY and GC7}

To determine the optimal IE in terms of inhibitor concentration and the duration of the pre-exposure time to the inhibitor, experiments were conducted at 2 stations (Stns 1 and 5, Fig. S1 in the Supplement and Table 1).

For the EMY-treated samples, leucine incorporation was similar in samples with a pre-exposure time of 30 and $60 \mathrm{~min}$ (4.8\% lower than at $30 \mathrm{~min})$. A concentration of $27 \mu \mathrm{mol} \mathrm{L}{ }^{-1}$ of EMY decreased bulk leucine incorporation to a similar level as the addition of $68 \mu \mathrm{mol}$ $\mathrm{L}^{-1}$ (Fig. 1, Holm-Sidak: $t=3.5, \mathrm{p}=0.177$ ). Based on these results, for all further experiments we used 
Table 3. Percentage of leucine-positive (Leu-pos.) picoplankton cells and cell-specific leucine uptake of specific microbial groups in the erythromycin (EMY) and N1-guanyl-1,7-diaminoheptane (GC7) treated samples and the untreated control (CTRL). WM: water masses (abbreviations as in Table 1). The percentage of Leu-pos. cells of DAPI-stained cells was calculated as mean \pm SD. Leucine uptake rates were calculated from bulk leucine incorporation (via scintillation counts) and silver-grain area attributed to group-specific probes

\begin{tabular}{|c|c|c|c|c|c|}
\hline $\begin{array}{l}\text { WM } \\
\text { Treatment }\end{array}$ & $\begin{array}{c}\text { Leu-pos. cells } \\
(\%)\end{array}$ & $\begin{array}{c}\text { Bacteria } \\
\left(\text { amol Leu cell }{ }^{-1} \mathrm{~d}^{-1}\right)\end{array}$ & $\begin{array}{c}\text { SAR11 } \\
\left(\text { amol Leu cell }{ }^{-1} \mathrm{~d}^{-1}\right)\end{array}$ & $\begin{array}{c}\text { Thaumarchaeota } \\
\left(\text { amol Leu cell }{ }^{-1} d^{-1}\right)\end{array}$ & $\begin{array}{c}\text { Euryarchaeota } \\
\left(\text { amol Leu cell }{ }^{-1} \mathrm{~d}^{-1}\right)\end{array}$ \\
\hline \multicolumn{6}{|l|}{ SSL $(n=5)$} \\
\hline CTRL & $47 \pm 9$ & $2.1 \pm 1.1$ & $1.7 \pm 1.0$ & $0.57 \pm 0.49$ & $0.82 \pm 0.71$ \\
\hline EMY & $28 \pm 18$ & $0.84 \pm 0.8$ & $0.34 \pm 0.22$ & $0.12 \pm 0.15$ & $0.09 \pm 0.08$ \\
\hline GC7 & $32 \pm 11$ & $1.8 \pm 1.2$ & $0.85 \pm 0.71$ & $0.40 \pm 0.35$ & $1.16 \pm 0.88$ \\
\hline \multicolumn{6}{|c|}{$\mathbf{O}_{2}-\min (\mathrm{n}=4)$} \\
\hline CTRL & $50 \pm 3$ & $0.39 \pm 0.28$ & $0.38 \pm 0.24$ & $0.12 \pm 0.06$ & $0.32 \pm 0.18$ \\
\hline EMY & $22 \pm 6$ & $0.15 \pm 0.08$ & $0.12 \pm 0.06$ & $0.047 \pm 0.038$ & $0.13 \pm 0.08$ \\
\hline \multicolumn{6}{|c|}{$\mathbf{u L S W}(\mathrm{n}=3)$} \\
\hline CTRL & $42 \pm 13$ & $0.13 \pm 0.07$ & $0.098 \pm 0.039$ & $0.013 \pm 0.007$ & $0.065 \pm 0.051$ \\
\hline EMY & $36 \pm 2$ & $0.042 \pm 0.023$ & $0.025 \pm 0.011$ & $0.013 \pm 0.007$ & $0.036 \pm 0.011$ \\
\hline GC7 & $48 \pm 22$ & $0.096 \pm 0.09$ & $0.085 \pm 0.033$ & $0.10 \pm 0.12$ & $0.11 \pm 0.09$ \\
\hline \multicolumn{6}{|c|}{$\mathbf{N S D W}(n=1)$} \\
\hline CTRL & 38 & 0.18 & 0.16 & 0.014 & 0.13 \\
\hline EMY & 22 & 0.12 & 0.081 & 0.010 & 0.027 \\
\hline GC7 & 39 & 0.13 & 0.13 & 0.030 & 0.054 \\
\hline
\end{tabular}

$68 \mu \mathrm{mol} \mathrm{L}{ }^{-1}$ of EMY (final concentration) and a preexposure time of $60 \mathrm{~min}$. This approach resulted in an inhibition of leucine incorporation of $75 \pm 6 \%(n=8)$, similar to that reported by Yokokawa et al. (2012).

In the GC7-treated samples, a final GC7 concentration of $1 \mathrm{mmol} \mathrm{L}^{-1}$ reduced the incorporation of leucine to $\sim 62 \%$ of the leucine incorporation of the untreated control (Fig. 1). A GC7 concentration of $0.1 \mathrm{mmol} \mathrm{L}^{-1}$ resulted in an $18 \%$ higher leucine incorporation than the $1 \mathrm{mmol} \mathrm{L}^{-1}$ treatments (HolmSidak: $t=40.4, \mathrm{p}=0.016)$. Inhibition of leucine incorporation by GC7 was similar in the $30 \mathrm{~min}$ and the 60 min pre-exposure time (Holm-Sidak: $t=1.99, \mathrm{p}=$ 0.296 ; Fig. 1). In all subsequent experiments, a $1 \mathrm{mmol} \mathrm{L}^{-1}$ final GC7 concentration and a pre-exposure time of 60 min were used.

The combined addition of the supposedly complementary inhibitors did not result in a complete inhibition of leucine incorporation (Fig. 1). Generally, most microorganisms are susceptible to antibiotics (Wilson 2014), although multidrug resistance is assumed to be widespread (Dunkle et al. 2010, Kohanski et al. 2010). More specifically, for a variety of pathogenic Bacteria, single and multidrug resistance has been reported (Levy \& Marshall 2004). Furthermore, several isolated soil Bacteria seem to be able to metabolize antibiotics as their sole carbon source (Dantas et al. 2008, but see also Walsh et al. 2013). According to Jansson et al. (2000), GC7 causes a reversible inhibition of archaeal cell growth. Thus, the polyamine could also stimulate the growth of resistant microorganisms. However, the effects of a drug combination on bacterial survival are manifold, ranging from additive to synergistic or antagonistic (Kohanski et al. 2010). Thus, we cannot exclude a suppression

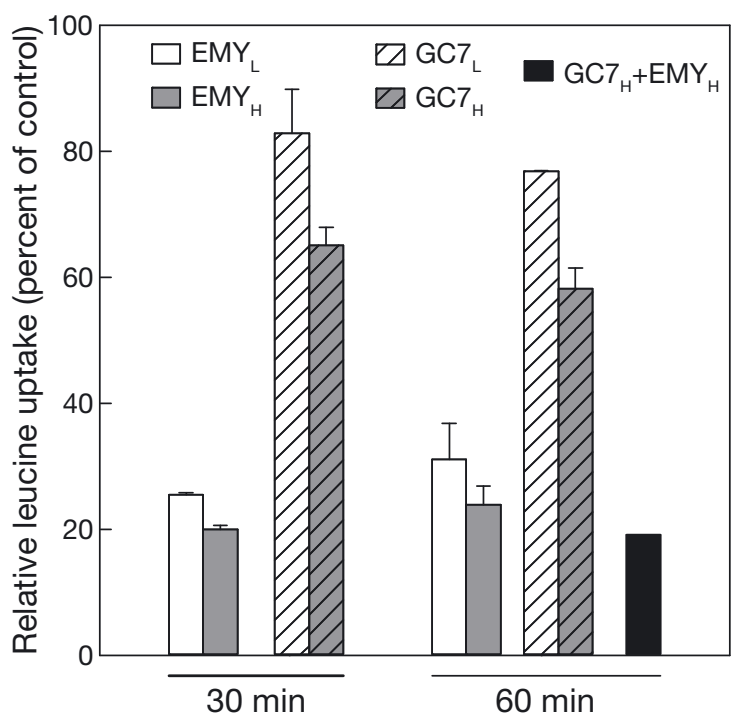

Fig. 1. Variation of inhibitor concentration and lag time. Relative leucine uptake of samples after addition of different concentrations of EMY and GC7 as a percentage of the respective control. Radiolabeled substrate was added after a preexposure time of 30 or $60 \mathrm{~min}$. Error bars represent the range of duplicate measurements. $\left(\mathrm{EMY}_{\mathrm{L}}=27 \mu \mathrm{mol} \mathrm{L}{ }^{-1}, \mathrm{EMY}_{\mathrm{H}}=\right.$ $68 \mu \mathrm{mol} \mathrm{L}-1, \mathrm{GC7}_{\mathrm{L}}=0.1 \mathrm{mmol} \mathrm{L}^{-1}, \mathrm{GC7}_{\mathrm{H}}=1.0 \mathrm{mmol} \mathrm{L}^{-1}$, where the sub-scripts, $L$ and $H$, are low and high, respectively) 
interaction (Chait et al. 2007, Kohanski et al. 2010) between EMY and GC7. This might, at least partly, explain the incomplete inhibition of leucine incorporation in the combined $\mathrm{EMY}+\mathrm{GC7}$ treatment resulting in a leucine incorporation amounting to $~ 19 \%$ of the untreated control (Fig. 1).

\section{Qualitative and quantitative assessment of IE and IS}

In the untreated control, approximately half of the DAPI-stained cells (46 $\pm 8 \%$ ) were taking up leucine throughout the water column. The EMY treatment generally resulted in a higher inhibition (41 $\pm 13 \%$ ) of leucine uptake than GC7 (17 $\pm 14 \%)$ based on the number of leucine-positive cells in the untreated controls (Table 3, Fig. S2 in the Supplement).

To investigate potential group-specific inhibition of leucine uptake induced by EMY and GC7, MICROCARD-FISH was used. The group-specific uptake was determined for the SAR11 clade, Bacteria, Thaumarchaeota, and Euryarchaeota, in both the inhibitor treatments and the respective controls (Fig. 2). In the untreated controls of the SSL, SAR11 contributed most to the picoplankton leucine uptake, while Thaumarchaeota and Euryarchaeota contributed only a minor fraction (Fig. 2A). The relative contribution of SAR11 to total leucine uptake decreased with depth, while the contribution of Thaumarchaeota and Euryarchaeota increased (Fig. 2D).

In EMY- and CG7-treated samples, bulk leucine uptake was reduced to 25 and $59 \%$, respectively, of the untreated controls (Fig. 2B,C). The percentage of leucine-positive cells in the EMY and GC7 treatments remained fairly constant over the entire depth range (Table 3 ). In contrast, the per-cell activity of all specific groups examined (Bacteria, SAR11, Thaumarchaeota, Euryarchaeota) decreased with depth by 1 order of magnitude in the untreated controls (Table 3). The contribution of Euryarchaeota was $\sim 3 \%$ and thus near the detection limit of the CARDFISH method, which we evaluated using a non-sense probe for hybridization (Table S1 in the Supplement). We therefore did not include Euryarchaeota in the assessment of the IE. Nevertheless, on the cellspecific level, the effect of the inhibitors was thoroughly investigated for Euryarchaeota.
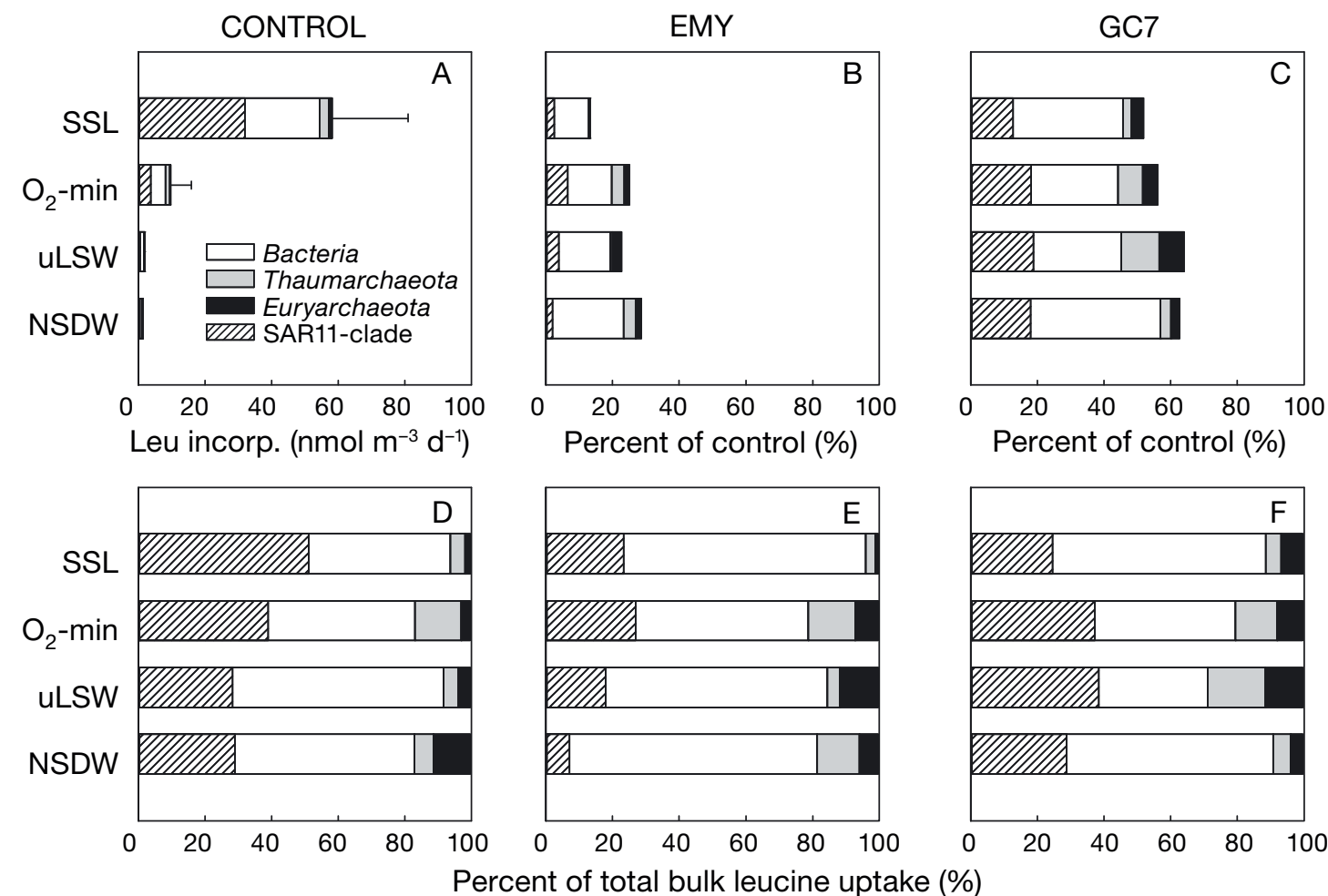

Fig. 2. Response of bulk and taxa-specific leucine uptake to inhibitors in different water masses. (A) Distribution of total bulk leucine uptake among several microbial taxa based on quantifying the silver-grain area attributed to the different taxonomic groups identified via MICRO-CARD-FISH. Leucine uptake of the different microbial taxa in percent of the untreated control following the addition of (B) EMY and (C) GC7 to samples of different water masses: subsurface layer (SSL), oxygen minimum $\left(\mathrm{O}_{2}\right.$-min), upper Labrador Sea Water (uLSW), and Norwegian Sea Deep Water (NSDW). Error bars in (A) represent the standard deviation of bulk leucine incorporation 


\section{Effect of EMY}

In EMY-treated samples, the distribution pattern of leucine uptake into the different taxa was similar to that in the untreated controls (Fig. 2D,E, Table S4 in the Supplement). The addition of EMY affected cell-specific activity of Bacteria and Thaumarchaeota similarly. Cell-specific bacterial activity, calculated on pairwise comparisons of EMYtreated incubations with the respective controls, decreased by $59 \pm 21 \%$ (Table 3 ). Thaumarchaeotal activity decreased by $52 \pm$ $38 \%$ as compared to the untreated controls. Euryarchaeotal activity decreased by $63 \pm$ $25 \%$, and cell-specific activity associated with the SAR-11 cluster decreased by $69 \pm 18 \%$ in the EMY treatments (Table 3). No significant difference between the different taxa was found in the percentage of inhibition in the EMY treatments as compared to the controls (Kruskal-Wallis 1-way ANOVA on ranks, $H=$ $2.0, \mathrm{df}=3, \mathrm{p}=0.572$ ). To assess the IE of EMY and GC7 for each taxonomic group, we calculated the reduction in the relative fraction of the leucine-positive cells for each inhibitor treatment compared to its control (Eqs. 2 \& 3). In addition to counting silver-grain-associated cells, the silver-grain halo area around each leucine-positive cell was calculated to obtain leucine uptake per cell (see 'Materials and methods' for details).

The IE of EMY, based on the abundance of leucine-positive cells, was variable, albeit similar for Bacteria $(38 \pm 25 \%)$ and Thaumarchaeota $(31 \pm 39 \%)\left(t_{20}=0.50, \mathrm{p}=0.31\right.$; Table 4). Likewise, the IE of leucine-positive cells calculated from the silver-grain halo area was not significantly different between Bacteria (78 $\pm 9 \%$ ) and Thaumarchaeota (76 \pm $14 \%)\left(t_{20}=0.43, \mathrm{p}=0.33\right.$; Table 4$)$. The IE considering the halo area is higher compared to the abundance-based IE. This indicates that leucine uptake of a considerable part of the community was not completely inhibited by EMY, but reduced to about $25 \%$ of its original value. Thus, the IS index, which is the relative difference in IE between the target and the non-target group normalized to the IE of the non-target group, was only $0.18 \pm 0.68$ (Table 4). This suggests that EMY caused a bacterial inhibition that was only $18 \%$ higher compared to the inhibition of the Thaumar-

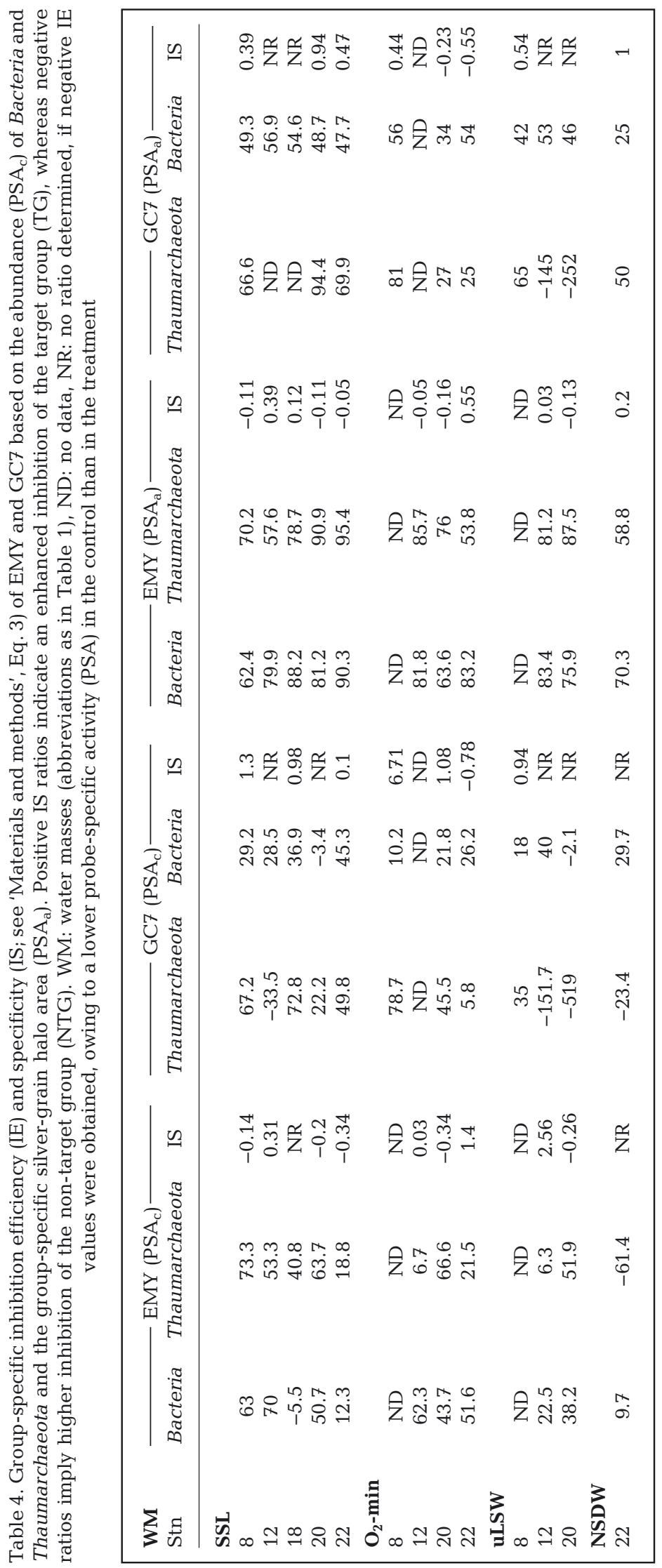


chaeota and not significantly different from 0 considering the large standard deviation. Clearly, EMY also severely affected Thaumarchaeota in our samples.

While EMY is assumed to be a specific inhibitor for Bacteria (Dunkle et al. 2010, Wilson 2014), reports suggest that horizontal gene transfer and/or mutations of ribosomal binding sites might alter the susceptibility to EMY in archaeal and bacterial species (Weisblum 1995, Tu et al. 2005, Dunkle et al. 2010). In the only study investigating the efficiency of EMY on a cell-specific level in natural complex communities, Yokokawa et al. (2012) suggested specific inhibition and an IE of $~ 90 \%$ on Bacteria. It is important to note, however, that all other studies concerning the efficiency of EMY are related to medically relevant organisms (e.g. Staphylococcus aureus) and do not consider natural prokaryotic assemblages.

\section{Effect of GC7}

The general tendency of the bulk leucine uptake between the investigated taxonomic groups in the GC7 treatments was very similar to the pattern observed in the controls (compare Fig. 2D,F and Table S4 in the Supplement). The average reduction in cell-specific leucine uptake, measured as the pairwise difference to the respective control, was generally low and variable, amounting to $17 \pm 57 \%$ for Thaumarchaeota as compared to $21 \pm 28 \%$ for Bacteria (Table 3). SAR11-associated cell-specific leucine uptake decreased by $36 \pm 51 \%$, while euryarchaeotal activity changed by $-7 \pm 71 \%$. No significant difference between the different taxa was found in the percentage of inhibition in the GC7 treatments as compared to the controls (Kruskal-Wallis 1-way ANOVA on ranks; $H=3.29, \mathrm{df}=3, \mathrm{p}=0.349$ ). In some samples, the GC7 treatment led to a higher cell-specific leucine uptake than in the untreated control (e.g. Thaumarchaeota in the NSDW). This stimulating effect was also reported earlier for GC7 (Yokokawa et al. 2012) and recently for diphteria toxin in archaeal enrichments from the Baltic Sea (Berg et al. 2015b).

The relatively high inhibition of Bacteria in GC7 treatments implied that GC7 is not as specific as previously assumed (Löscher et al. 2012). The IE based on the number of leucine-positive cells was not significantly different between Thaumarchaeota (48 \pm $73 \%)$ and Bacteria $(29 \pm 35 \%)$, even after removing samples in which a stimulation of leucine uptake was found (Table 4, Mann-Whitney $U$-test: $U=20, \mathrm{p}=$ 0.083). Similarly, using the silver-grain halo area to calculate the IE resulted in an insignificantly higher inhibition of Thaumarchaeota (median $=66 \%$, range $=69 \%$ ) than of Bacteria (median $=49 \%$, range $=$ $32 \%$ ) (Table 4, Mann-Whitney $U$-test: $U=27.5, \mathrm{p}=$ 0.123 ). The average IS of GC7 was $0.89 \pm 1.72$, indicating an $89 \%$ higher inhibition of Thaumarchaeota than of Bacteria (Table 4). However, the large standard deviation of IS $(172 \%)$ suggests a rather low specificity of the inhibitor GC7. Thus, our data strongly suggest that Bacteria are susceptible to GC7. Remarkably, Jansson et al. (2000) already reported an increased turnover time of Escherichia coli by $\sim 30 \%$ when grown in a solution containing $1 \mathrm{mM}$ GC7. They concluded that an elevated polyamine level, modulating the functions of RNA, DNA, nucleotide triphosphates, proteins, and other acidic substances within bacterial cells (Igarashi \& Kashiwagi 2000), might be responsible for unspecific effects, causing the delay in cell growth. Moreover, it was shown that the elongation factor eF-5A, associated with cell proliferation, is rather stable in mammalian cells (Nishimura et al. 2005). This would argue for long pre-exposure periods of several days until GC7 shows an inhibitory effect. Recently, Oliverio et al. (2014) found that GC7 can affect cell-constituting processes by mechanisms other than inhibition of the DHS, which transfers the aminobutyryl moiety of the polyamine spermidine to the $\varepsilon$-amine of a conserved lysine in the precursor of the elongation factor to form deoxyhypusine. Thus, the mechanism by which Bacteria are affected by GC7 is not necessarily due to a reaction with DHS, which was the basis for the selection of this inhibitor as being specific. Based on a few archaeal isolates, specific inhibition of archaeal activity by GC7 was reported (Löscher et al. 2012, Berg et al. 2015b). Thus far, the assessment of IS on the bases of cell-specific evaluation has only been conducted under artificial (culture) conditions and tested with selected model organisms (e.g. Jansson et al. 2000, Kannan \& Mankin 2011, Löscher et al. 2012). Initially, GC7 was proposed simply as a cheaper alternative to diphtheria toxin to inhibit archaeal activity. According to recent studies, however, the specificity of diphtheria toxin might have adverse and non-inhibitory effects as well (Berg et al. 2015a).

\section{CONCLUSIONS}

Taken together, our data suggest that the addition of EMY to open-ocean microbial communities inhibits leucine incorporation of Bacteria and Archaea to a similar degree. Moreover, GC7, meant to be an Archaea-specific inhibitor, reduces leucine uptake of 
Archaea and Bacteria to an unspecific, but variable extent. This indicates that the inhibitors EMY and GC7 are not as specific as commonly assumed. Furthermore, our findings indicate that inhibitory substances need to be carefully tested on a single-cell level in the relevant natural environment before being applied to a bulk community level to differentiate activity rates among different microbial groups.

Acknowledgements. We thank the captain and crew of the RV 'Pelagia' for their help at sea. This research was funded by the European Research Council under the European Community's Seventh Framework Program (FP7/2007-2013) / ERC grant agreement No. 268595 (MEDEA project) and the Austrian Science Fund (FWF) projects: I486-B09 and P23234-B11 (all to G.J.H.) and the Austrian Science Fund (FWF) project PADOM (P 23221-B11) to T.R. This work was done in partial fulfillment of the requirements for a $\mathrm{PhD}$ degree from the University of Vienna to A.H.F. We have no conflicts of interest to declare.

\section{LITERATURE CITED}

Bartig D, Lemkemeier K, Frank J, Lottspeich F, Klink F (1992) The archaebacterial hypusine-containing protein. Structural features suggest common ancestry with eukaryotic translation initiation factor 5A. Eur J Biochem 204:751-758

> Berg C, Vandieken V, Thamdrup B, Jürgens K (2015a) Significance of archaeal nitrification in hypoxic waters of the Baltic Sea. ISME J 9:1319-1332

> Berg C, Listmann L, Vandieken V, Vogts A, Jürgens K (2015b) Chemoautotrophic growth of ammonia-oxidizing Thaumarchaeota enriched from a pelagic redox gradient in the Baltic Sea. Front Microbiol 5:786

> Brochier C, Lopez-Garcia P, Moreira D (2004) Horizontal gene transfer and archaeal origin of deoxyhypusine synthase homologous genes in bacteria. Gene 330: 169-176

Cavicchioli R, Curmi PMG, Saunders N, Thomas T (2003) Pathogenic archaea: Do they exist? BioEssays 25: 1119-1128

Chait R, Craney A, Kishony R (2007) Antibiotic interactions that select against resistance. Nature 446:668-671

Church MJ, DeLong EF, Ducklow HW, Karner MB, Preston CM, Karl DM (2003) Abundance and distribution of planktonic Archaea and Bacteria in the waters west of the Antarctic Peninsula. Limnol Oceanogr 48:1893-1902

> Dantas G, Sommer MOA, Oluwasegun RD, Church GM (2008) Bacteria subsisting on antibiotics. Science 320: 100-103

> De Corte D, Sintes E, Yokokawa T, Herndl GJ (2013) Comparison between MICRO-CARD-FISH and 16S rRNA gene clone libraries to assess the active versus total bacterial community in the coastal Arctic. Environ Microbiol Rep 5:272-281

- Ducklow HW, Dickson ML, Kirchman DL, Steward G, Orchardo J, Marra J, Azam F (2000) Constraining bacterial production, conversion efficiency and respiration in the Ross Sea, Antarctica, January-February, 1997. DeepSea Res II 47:3227-3247
Dunkle JA, Xiong LQ, Mankin AS, Cate JHD (2010) Structures of the Escherichia coli ribosome with antibiotics bound near the peptidyl transferase center explain spectra of drug action. Proc Natl Acad Sci USA 107: 17152-17157

Eckburg PB, Lepp PW, Relman DA (2003) Archaea and their potential role in human disease. Infect Immun 71: 591-596

Eichler J, Adams MW (2005) Posttranslational protein modification in Archaea. Microbiol Mol Biol Rev 69:393-425

Farias L, Fernandez C, Faundez J, Cornejo M, Alcaman ME (2009) Chemolithoautotrophic production mediating the cycling of the greenhouse gases $\mathrm{N}_{2} \mathrm{O}$ and $\mathrm{CH}_{4}$ in an upwelling ecosystem. Biogeosciences 6:3053-3069

> Francis CA, Beman JM, Kuypers MMM (2007) New processes and players in the nitrogen cycle: the microbial ecology of anaerobic and archaeal ammonia oxidation. ISME J 1:19-27

> Gordon ED, Mora R, Meredith SC, Lee C, Lindquist SL (1987) Eukaryotic initiation factor 4D, the hypusinecontaining protein, is conserved among eukaryotes. J Biol Chem 262:16585-16589

> Hallam SJ, Mincer TJ, Schleper C, Preston CM, Roberts K, Richardson PM, DeLong EF (2006) Pathways of carbon assimilation and ammonia oxidation suggested by environmental genomic analyses of marine Crenarchaeota. PLoS Biol 4(4):e95

> Herndl GJ, Reinthaler T, Teira E, van Aken H, Veth C, Pernthaler A, Pernthaler J (2005) Contribution of Archaea to total prokaryotic production in the deep Atlantic Ocean. Appl Environ Microbiol 71:2303-2309

> Igarashi K, Kashiwagi K (2000) Polyamines: mysterious modulators of cellular functions. Biochem Biophys Res Commun 271:559-564

> Jansson BP, Malandrin L, Johansson HE (2000) Cell cycle arrest in archaea by the hypusination inhibitor N(1)guanyl-1,7-diaminoheptane. J Bacteriol 182:1158-1161

Kannan K, Mankin AS (2011) Macrolide antibiotics in the ribosome exit tunnel: species-specific binding and action. Ann N Y Acad Sci 1241:33-47

Karner MB, DeLong EF, Karl DM (2001) Archaeal dominance in the mesopelagic zone of the Pacific Ocean. Nature 409:507-510

Kessel M, Klink F (1980) Archaeobacterial elongation-factor is ADP-ribosylated by diphtheria-toxin. Nature 287: 250-251

Kohanski MA, Dwyer DJ, Collins JJ (2010) How antibiotics kill bacteria: from targets to networks. Nat Rev Microbiol 8:423-435

Könneke M, Bernhard AE, de la Torre JR, Walker CB, Waterbury JB, Stahl DA (2005) Isolation of an autotrophic ammonia-oxidizing marine archaeon. Nature 437:543-546

Kyrpides NC, Woese CR (1998) Universally conserved translation initiation factors. Proc Natl Acad Sci USA 95: 224-228

Lekunberri I, Sintes E, de Corte D, Yokokawa T, Herndl GJ (2013) Spatial patterns of bacterial and archaeal communities along the Romanche Fracture Zone (tropical Atlantic). FEMS Microbiol Ecol 85:537-552

> Levipan HA, Quinones RA, Johansson HE, Urrutia H (2007a) Methylotrophic methanogens in the water column of an upwelling zone with a strong oxygen gradient off central Chile. Microbes Environ 22:268-278

> Levipan HA, Quinones RA, Urrutia H (2007b) A time series 
of prokaryote secondary production in the oxygen minimum zone of the Humboldt current system, off central Chile. Prog Oceanogr 75:531-549

Levy SB, Marshall B (2004) Antibacterial resistance worldwide: causes, challenges and responses. Nat Med 10: S122-S129

López-García P, Brochier C, Moreira D, Rodríguez-Valera F (2004) Comparative analysis of a genome fragment of an uncultivated mesopelagic crenarchaeote reveals multiple horizontal gene transfers. Environ Microbiol 6:19-34

Löscher CR, Kock A, Konneke M, LaRoche J, Bange HW, Schmitz RA (2012) Production of oceanic nitrous oxide by ammonia-oxidizing archaea. Biogeosciences 9: 2419-2429

> Marie D, Partensky F, Jacquet S, Vaulot D (1997) Enumeration and cell cycle analysis of natural populations of marine picoplankton by flow cytometry using the nucleic acid stain SYBR Green I. Appl Environ Microbiol 63: 186-193

> Martin-Cuadrado AB, Rodriguez-Valera F, Moreira D, Alba JC and others (2008) Hindsight in the relative abundance, metabolic potential and genome dynamics of uncultivated marine archaea from comparative metagenomic analyses of bathypelagic plankton of different oceanic regions. ISME J 2:865-886

Murphey RJ, Gerner EW (1987) Hypusine formation in protein by a two-step process in cell lysates. J Biol Chem 262:15033-15036

Nishimura K, Murozumi K, Shirahata A, Park MH, Kashiwagi K, Igarashi K (2005) Independent roles of eIF5A and polyamines in cell proliferation. Biochem J 385:779-785

Oliverio S, Corazzari M, Sestito C, Piredda L, Ippolito G, Piacentini $M$ (2014) The spermidine analogue GC7 (N1-guanyl-1,7-diamineoheptane) induces autophagy through a mechanism not involving the hypusination of eIF5A. Amino Acids 46:2767-2776

Ouverney CC, Fuhrman JA (2000) Marine planktonic Archaea take up amino acids. Appl Environ Microbiol 66:4829-4833

Park JH, Aravind L, Wolff EC, Kaevel J, Kim YS, Park MH (2006) Molecular cloning, expression, and structural prediction of deoxyhypusine hydroxylase: a HEAT-repeatcontaining metalloenzyme. Proc Natl Acad Sci USA 103: 51-56

Park MH, Nishimura K, Zanelli CF, Valentini SR (2010) Functional significance of eIF5A and its hypusine modification in eukaryotes. Amino Acids 38:491-500

Reinthaler T, van Aken H, Veth C, Aristegui J and others (2006) Prokaryotic respiration and production in the meso- and bathypelagic realm of the eastern and western North Atlantic basin. Limnol Oceanogr 51:1262-1273

Reinthaler T, van Aken HM, Herndl GJ (2010) Major contribution of autotrophy to microbial carbon cycling in the deep North Atlantic's interior. Deep-Sea Res II 57: 1572-1580

Reinthaler T, Salgado XAA, Alvarez M, van Aken HM, Herndl GJ (2013) Impact of water mass mixing on the biogeochemistry and microbiology of the Northeast Atlantic Deep Water. Global Biogeochem Cycles 27: 1151-1162

Editorial responsibility: Hans-Georg Hoppe, Kiel, Germany
Samo TJ, Smriga S, Malfatti F, Sherwood BP, Azam F (2014) Broad distribution and high proportion of protein synthesis active marine bacteria revealed by click chemistry at the single cell level. Front Mar Sci 1:48

Simon M, Azam F (1989) Protein content and protein synthesis rates of planktonic marine bacteria. Mar Ecol Prog Ser 51:201-213

Sintes E, Herndl GJ (2006) Quantifying substrate uptake by individual cells of marine bacterioplankton by catalyzed reporter deposition fluorescence in situ hybridization combined with micro autoradiography. Appl Environ Microbiol 72:7022-7028

- Teira E, Reinthaler T, Pernthaler A, Pernthaler J, Herndl GJ (2004) Combining catalyzed reporter deposition-fluorescence in situ hybridization and microautoradiography to detect substrate utilization by Bacteria and Archaea in the deep ocean. Appl Environ Microbiol 70:4411-4414

> Teira E, Lebaron P, van Aken H, Herndl GJ (2006a) Distribution and activity of Bacteria and Archaea in the deep water masses of the North Atlantic. Limnol Oceanogr 51: 2131-2144

> Teira E, van Aken H, Veth C, Herndl GJ (2006b) Archaeal uptake of enantiomeric amino acids in the meso- and bathypelagic waters of the North Atlantic. Limnol Oceanogr 51:60-69

Tu D, Blaha G, Moore PB, Steitz TA (2005) Structures of $\mathrm{MLS}_{\mathrm{B}} \mathrm{K}$ antibiotics bound to mutated large ribosomal subunits provide a structural explanation for resistance. Cell 121:257-270

Umland TC, Wolff EC, Park MH, Davies DR (2004) A new crystal structure of deoxyhypusine synthase reveals the configuration of the active enzyme and of an enzyme. NAD'inhibitor ternary complex. J Biol Chem 279: 28697-28705

> Varela MM, van Aken HM, Sintes E, Herndl GJ (2008) Latitudinal trends of Crenarchaeota and Bacteria in the meso- and bathypelagic water masses of the Eastern North Atlantic. Environ Microbiol 10:110-124

Varela MM, van Aken HM, Sintes E, Reinthaler T, Herndl GJ (2011) Contribution of Crenarchaeota and Bacteria to autotrophy in the North Atlantic interior. Environ Microbiol 13:1524-1533

- Walsh F, Amyes SGB, Duffy B (2013) Challenging the concept of bacteria subsisting on antibiotics. Int $\mathrm{J}$ Antimicrob Agents 41:558-563

Weisblum B (1995) Erythromycin resistance by ribosome modification. Antimicrob Agents Chemother 39:577-585

Wilson DN (2014) Ribosome-targeting antibiotics and mechanisms of bacterial resistance. Nat Rev Microbiol 12: 35-48

Wuchter C, Abbas B, Coolen MJL, Herfort L and others (2006) Archaeal nitrification in the ocean. Proc Natl Acad Sci USA 103:12317-12322

Yokokawa T, Sintes E, De Corte D, Olbrich K, Herndl GJ (2012) Differentiating leucine incorporation of Archaea and Bacteria throughout the water column of the eastern Atlantic using metabolic inhibitors. Aquat Microb Ecol 66:247-256

Zanelli CF, Valentini SR (2007) Is there a role for eIF5A in translation? Amino Acids 33:351-358

Submitted: March 7, 2016; Accepted: June 27, 2016

Proofs received from author(s): August 5, 2016 